\title{
Bentuk - Bentuk Penyesuaian Ruang Unit Hunian di Rusunawa Kota Pontianak
}

\author{
Lestari; Hamdil Khaliesh; Zairin Zain; Indah Kartika Sari \\ Program Studi Arsitektur, Universitas Tanjungpura, \\ Jl. Prof. Hadari Nawawi Pontianak, Indonesia \\ lestari@teknik.untan.ac.id
}

\begin{abstract}
The Government of Pontianak have built rusunawa (low cost rent apartemen) in Sungai Beliung, West Pontianak to solve the problem of housing needs. Rusunawa residents from various backgrounds and characteristics are facilitated with same dwelling unit design and same size is $24 \mathrm{~m} 2$. Same dwelling units, with various residents backgrounds and characteristics, allow residents to make adjustments to dwelling units including the use of space available for occupant activities. This paper aims to describe the form of space utilization as well as the occupant adjustment made to a dwelling unit. The expectations are could be consideration to the design of the next rusunawa. The method is performed through observation on 30 samples of dwelling units, and interviews to determine the another factors of the occupant. As results, there are several types of space utilization and adjustment of dwelling units. Utilization of the space tended to be formed due to facilitating occupant activities. Adjustments with changing the furniture provided in accordance with the needs of residents.
\end{abstract}

Keywords : dwelling units, utilization, adjustments, rusunawa.

\begin{abstract}
Abstrak
Untuk menyelesaikan permasalahan kebutuhan hunian, Pemerintah Kota Pontianak membangun rusunawa di Sungai Beliung, Pontianak Barat. Penghuni rusunawa terdiri dari berbagai latar belakang dan karakteristik yang difasilitasi dengan unit hunian dengan desain dan luasan yang seragam yaitu tipe 24. Unit hunian yang seragam, dengan penghuni yang memiliki latar belakang dan karakteristik yang beragam memungkinkan terjadinya penyesuaian-penyesuaian yang dilakukan oleh penghuni terhadap unit hunian termasuk dalam pemanfaatan ruang yang tersedia untuk kegiatan penghuni. Tulisan ini bertujuan memaparkan bentuk pemanfaatan ruang serta penyesuaian yang dilakukan pada unit hunian di rusunawa Kota Pontianak dengan harapan menjadi bahan masukan untuk desain rusunawa berikutnya. Metode yang dilakukan melalui observasi pada 30 sampel unit hunian, yang diperkuat dengan wawancara terhadap penghuni untuk mengetahui faktor penghuni yang mempengaruhi. Hasil yang diperoleh dapat dilihat bahwa ada beberapa tipe pemanfaatan dan penyesuaian ruang unit hunian. Pemanfaatan ruang tersebut cenderung terbentuk akibat pewadahan kegiatan penghuni. Penyesuaian lebih mengarah pada perubahan perabot yang tersedia sesuai dengan kebutuhan penghuni.
\end{abstract}

Kata kunci : unit hunian; pemanfaatan; penyesuaian; rusunawa;

\section{PENDAHULUAN}

Pemerintah kota Pontianak berusaha memenuhi kebutuhan hunian melalui pembangunan rusunawa (rumah susun sederhana sewa). Salah satu rusunawa yang dibangun oleh Pemerintah Kota Pontianak berada di kelurahan Sungai Beliung Kecamatan Pontianak Barat. Selain memfasilitasi kebutuhan masyarakat yang tidak mampu memiliki rumah sendiri, tingginya harga lahan menjadi salah satu alasan pemerintah Pontianak membangun rusunawa tersebut. Pada mulanya rusunawa tersebut diperuntukkan terutama untuk masyarakat yang tinggal di pinggir sungai Kapuas yang terpaksa harus dipindahkan karena menempati lahan yang tidak 
sesuai peruntukannya. Pada masa berikutnya, rusunawa tersebut juga dihuni oleh berbagai masyarakat yang berpenghasilan rendah (MBR) seiring dengan beragamnya keinginan dari penghuni dan kebijakan yang ditetapkan oleh pemerintah Kota Pontianak.

Rusunawa di kelurahan Sungai Beliung Kecamatan Pontianak Barat merupakan rusunawa yang dibangun dengan unit hunian tipe 24. Bangunan rusunawa terdiri dari 2 blok 5 lantai yang terletak bersebelahan. Keseluruhan unit hunian terdiri dari 96 unit hunian ditambah dengan 3 unit hunian khusus diffable. Setiap unit hunian terdiri dari satu kamar, satu ruang tamu, satu kamar mandi, dapur serta balkon. Antar unit hunian dalam satu lantai dihubungkan dengan selasar, sedangkan antar lantai bangunan dihubungkan dengan tangga.

Keberagaman latar belakang, jumlah penghuni dan keterbatasan ruang yang tersedia dalam hunian mempengaruhi cara-cara penghuni memanfaatkan ruang. Kebijakan pemerintah Kota Pontianak memberikan batasan jumlah penghuni dalam 1 unit hunian, yaitu maksimal 3 penghuni untuk setiap unit, terkecuali tambahan penghuni usia balita. Penghuni terdiri dari latar belakang suku, pekerjaan, agama dan usia yang mempengaruhi kebutuhan dan kegiatan yang dilakukan oleh penghuni di unit huniannya. Perbedaan kebutuhan dan kegiatan tersebut harus dilakukan pada unit hunian dengan luas dan desain yang sama. Jumlah ruang yang tersedia dan keterbatasan luasan memunculkan usaha penghuni untuk melakukan penyesuaian dalam memanfaatkan ruang sesuai dengan kebutuhannya. Dari berbagai cara penghuni menyesuaikan ruang akan dilihat kemiripan-kemiripan yang muncul dalam memanfaatkan ruang unit hunian tersebut. Kemiripan ini kemungkinan terjadi akibat adanya kebutuhan yang sama dan adanya peluang dalam perubahan ruang. Peneltian ini bertujuan untuk mengetahui bentuk-bentuk penyesuaian dalam pemanfaatan ruang unit hunian dari berbagai karakter penghuni tersebut. Dengan demikian diharapkan dapat diketahui kebutuhan penghuni rusunawa secara umum dan penghuni rusunawa kota Pontianak secara khusus, yang diharapkan memberikan masukan dalam perancangan rusunawa pada masa berikutnya.

\section{METODE}

Penelitian ini dilakukan dengan menganalisis bentuk penyesuaian dalam memanfaatkan ruang dari fungsi awal ruang unit hunian berdasarkan perencanaan dengan kondisi eksisting unit hunian setelah di huni.

Data kondisi awal saat perencanaan menggunakan data sekunder gambargambar rencana pembangunan beserta keterangan dari penghuni dan pengelola, sedangkan data kondisi eksisting diperoleh dengan melakukan observasi untuk melihat fisik dan penggunaan ruang yang didukung dengan keterangan dari penghuni. Hasil identifikasi kemudian dikelompokkan untuk mendapatkan beberapa tipe bentuk penyesuaian yang dilakukan oleh penghuni berdasarkan kemiripan yang ada. Pemanfaatan ruang tersebut kemudian dikaitkan dengan kondisi penghuni terutama jumlah penghuni dan kegiatan dalam hunian. Penelitian yang dilakukan di lokasi rusunawa Kota Pontianak, di kelurahan Sungai Beliung, Jalan Kom Yos Sudarso ini hanya di fokuskan pada unit hunian rusunawa. Dari keseluruhan 96 unit hunian pada rusunawa tersebut, diambil sampel sebanyak 30 unit hunian. Sampelsampel tersebut diambil dari kedua blok hunian dengan masing-masing blok diambil 15 buah sampel, yang kemudian dari masing-masing lantai diambil 3-4 unit hunian sebagai sampel.

\section{KAJIAN TEORI}

Desain rumah memerlukan fleksibilitas untuk menanggapi berbagai perubahan yang mungkin diperlukan oleh penghuni sesuai dengan tuntutan kebutuhannya (Agrawal, 2006). Hal ini disebabkan karena lingkungan fisik yang 
dirancang untuk memenuhi kebutuhan menurut Laurens (2004) terkadang mempertimbangkan kebutuhan manusia secara umum namun tidak memperhatikan kebutuhan atau persepsi pengguna secara spesifik. Menurut Sarwono (2006), setiap orang akan berusaha melakukan penyesuaian - penyesuaian terhadap lingkungan agar sesuai dengan keinginan dan kebutuhannya. Ada dua jenis penyesuaian yang dilakukan seseorang yaitu adaptasi dan adjusment. Adaptasi merupakan bentuk penyesuaian individu terhadap lingkungan dengan cara merubah dirinya agar sesuai dengan lingkungan, sedangkan adjusment merupakan bentuk usaha manusia untuk menyesuaikan keadaan lingkungan dengan merekayasa lingkungannya. Proses penyesuaian seringkali muncul karena adanya ketidaksesuaian kebutuhan dengan perencanaan awal, sehingga muncul pemanfaatan ruang yeng tersedia untuk kebutuhan tersebut misalnya ruang untuk aktivitas komunal menggunakan ruang yang bukan direncanakan untuk ruang komunal (Purwanto, 2012). Hal ini untuk meningkatkan rasa memiliki suatu tempat dengan nilai positif sebagai karakteristik lingkungan tempat tinggalnya. (Tester, et al., 2011).

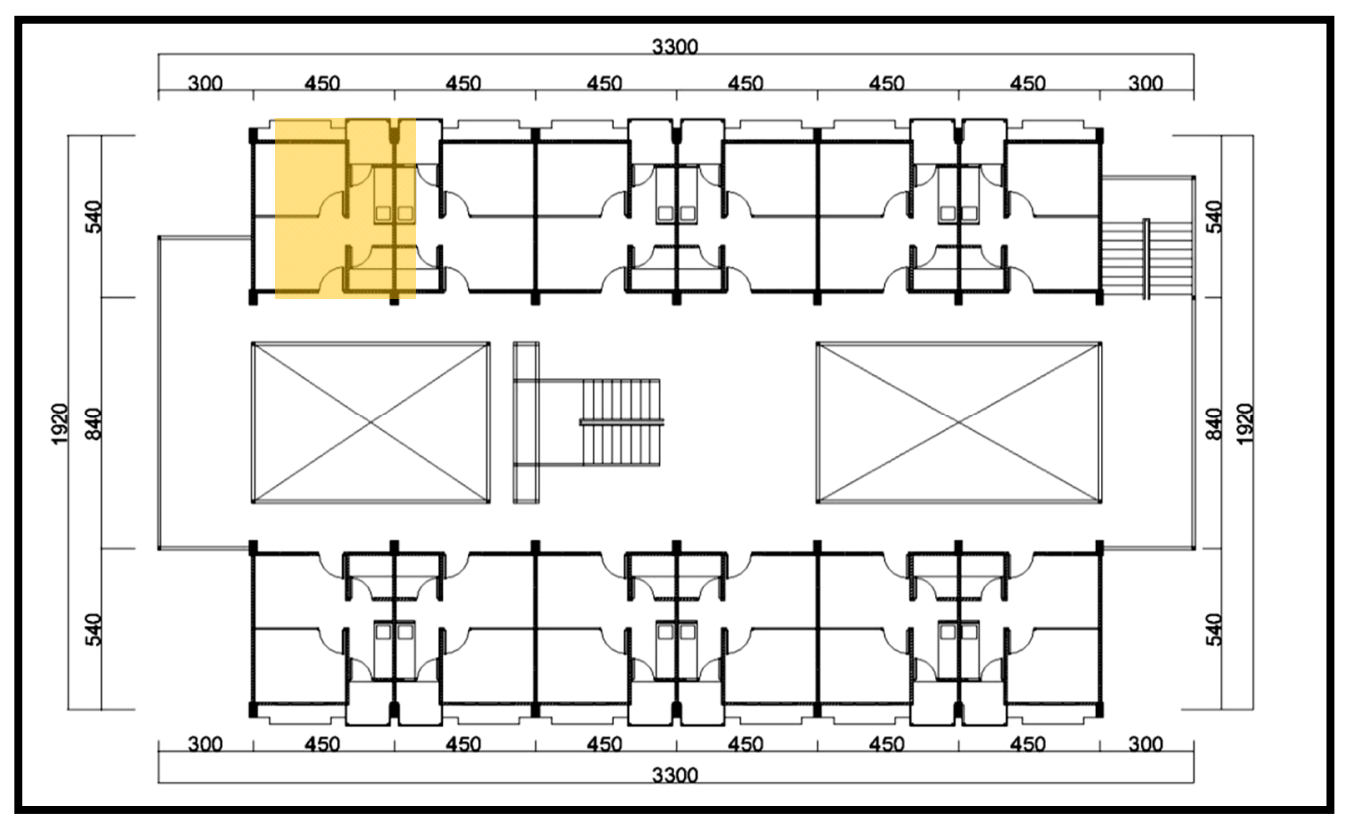

Gambar 1: Denah 1 unit hunian dalam 1 blok bangunan Rusunawa Kota Pontianak (Sumber : Departemen PU, Dirjen Cipta Karya, 2006 dengan modifikasi oleh Penulis, 2017)

Perubahan dalam ruang hunian rusunawa sebagai bentuk penyesuaian, juga dilakukan untuk memenuhi kebutuhan penghuni berdasarkan ketersediaan ruang - ruang yang ada. Penghuni yang menyatakan puas terhadap hunian mereka umumnya menyarankan untuk melakukan perubahan unit hunian berdasarkan kebutuhan rumah tangganya (Ibem, E.O., 2012). Hal ini dapat disebabkan karena kebutuhan dan perilaku dapat memanfaatkan ruang apa saja yang tersedia. Penghuni rumah susun juga berasal dari berbagai karakteristik dan latar belakang yang berbeda (Zain, 2015) sehingga kebutuhan juga akan beragam. Kondisi ruang-ruang hunian yang sangat berdekatan antara unit satu dengan unit lainnya, menyebabkan penyesuaian terkadang juga menjadi cara untuk mendapatkan privasi penghuni. Oleh karena itu, perencanaan ruang 
bersama seharusnya mempertimbangkan penempatannya sehingga dapat tenang dan menjaga privasi dari hunian (Darmiwati, 2000). Namun bentuk perubahan fisik hanya dapat dilakukan oleh penghuni dengan mengubah layout dan perabot non permanen. Pemanfaatan balkon sebagai penghijauan merupakan alternatif yang dapat menambah nilai estetika (Septyadinda \& Sari \& Hariyono, 2013).

\section{PEMBAHASAN}

\section{Pemanfaatan ruang-ruang hunian}

Rusunawa yang menjadi objek penelitian ini berupa bangunan lima lantai yang terbagi menjadi dua blok yang bersebelahan. Seluruh unit hunian direncanakan dengan tipe 24. Dalam 1 unit hunian hanya terdapat terdapat 5 ruang yaitu satu kamar, satu ruang tamu, satu kamar mandi, dapur serta balkon. Terdapat 6 unit hunian yang berdampingan dalam satu sisi deret di tiap lantai bangunan. Terdapat 2 deret hunian tiap lantai yang terhubung dengan selasar. Antar lantai bangunan dihubungkan dengan tangga. Gambaran mengenai ruang - ruang yang terdapat dalam 1 unit hunian pada keadaan pada saat perencanaan dapat dilihat pada Gambar 2.

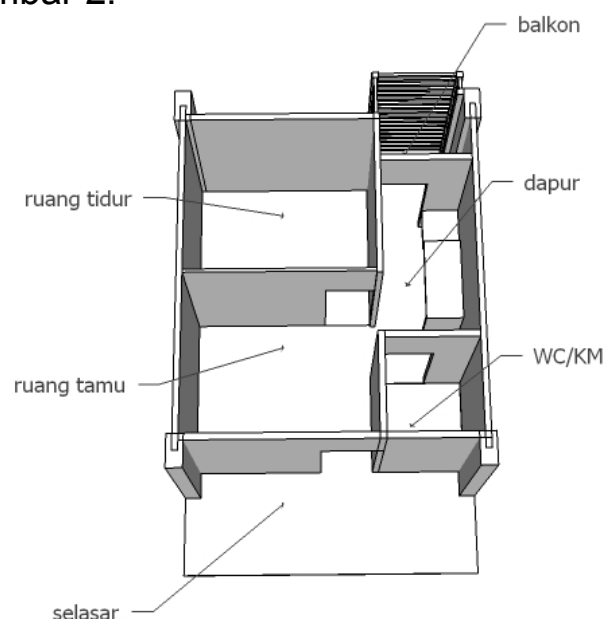

Gambar 2: Denah 1 unit hunian Rusunawa Kota Pontianak

(Sumber : Departemen PU, Dirjen Cipta Karya, 2006 dengan modifikasi oleh Penulis, 2017)

Berdasarkan hasil observasi terhadap unit-unit hunian yang telah dilakukan, bentuk penyesuaian yang dilakukan oleh penghuni dalam memanfaatkan ruang yang tersedia dapat dikelompokkan menjadi beberapa bentuk. Merujuk pada Zairin, (2015) karakterisik unit hunian pada rusunawa kota Pontianak didasarkan pada kebutuhan penghuni yaitu untuk memfasilitasi kegiatan - kegiatan yang utama dilakukan oleh penghuni. Kegiatan rutin yang selalu dilakukan oleh hampir seluruh penghuni adalah tidur, berkumpul bersama keluarga, memasak dan makan, mandi, mencuci dan menjemur. Kegiatan yang dilakukan sebagian penghuni antara lain kegiatan menyalurkan hobi seperti berkebun. Pembahasan dikelompokkan berdasarkan pemanfaatan ruang - ruang yag tersedia untuk memfasilitasi kegiatan tersebut, kemudian mengelompokkan menjadi beberapa bentuk berdasarkan kemiripan dalam memanfaatkan ruang.

\section{Pemanfaatan ruang selasar}

Selasar bukan merupakan ruang pribadi. Walaupun demikian pada kasus rusunawa kota Pontianak, sering digunakan sebagai ruang pribadi penghuni baik dalam beraktivitas maupun untuk meletakkan barang atau perabot. Berdasarkan hasil observasi yang dilakukan, ada beberapa kegiatan dan penyesuaian yang dilakukan oleh penghuni pada bagian selasar. Kegiatan pada bagian selasar tersebut adalah aktivitas menjemur, bersantai atau menerima tamu, dan menempatkan barang. Aktivitas menjemur ditemui dibeberapa sampel hunian yang memanfaatkan ruang selasar sebagai tempat menjemur pakaian. Peralatan menjemur yang digunakan adalah yang dapat dipindahkan (tidak permanen). Penempatan peralatan menjemur tersebut menjadi salah satu bagian yang memperkuat bahwa aktivitas menjemur dilakukan dibagian selasar. Selain untuk digunakan untuk aktivitas menjemur, pada ruang selasar juga banyak dijumpai kursikursi milik penghuni yang sengaja diletakkan di bagian selasar untuk aktivitas bersantai. Bagi penghuni, kursi yang diletakkan di bagian selasar dapat berfungsi pula untuk menyambut tamu tidak privat atau sekedar mengobrol 
dengan tetangga hunian lain. Ruang selasar juga banyak digunakan untuk menempatkan barang-barang milik penghuni unit seperti meletakkan rak sepatu atau peralatan kebersihan, termasuk barang-barang milik dari kegiatan hobi seperti sangkar burung (Gambar 3).

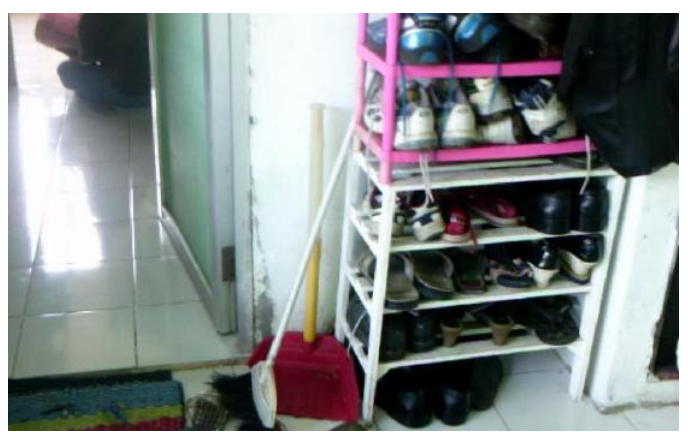

Gambar 3: Pemanfaatan selasar untuk menempatkan barang

(Sumber : Penulis, 2017)

\section{Pemanfaatan ruang tamu}

Ada beberapa kegiatan yang dilakukan oleh penghuni pada ruang tamu. Ruang tamu digunakan sebagai ruang keluarga atau ruang berkumpul, ruang menerima tamu, perluasan kamar, perluasan dapur dan ruang untuk menempatkan barang - barang. Penggunaan ruang tamu sebagai ruang keluarga dilihat dari penempatan perabot seperti televisi dan kasur untuk menonton. Beberapa hunian memanfaatkan ruang tamu untuk aktivitas menerima tamu, dapat dilihat dari penempatan kursi dan meja tamu pada ruang tersebut. Hunian yang seperti ini biasanya memfungsikan ruang tamu selain sebagai ruang untuk menerima tamu, sekaligus sebagai ruang berkumpul atau menonton tv (Gambar 4 dan Gambar 5). Selain itu, ruang tamu juga difungsikan sebagai ruang untuk menempatan barang-barang atau bahkan sebagai ruang makan, perluasan area kamar (untuk tidur dan menempatkan lemari pakaian), dan perluasan daerah dapur (untuk aktifitas memasak).

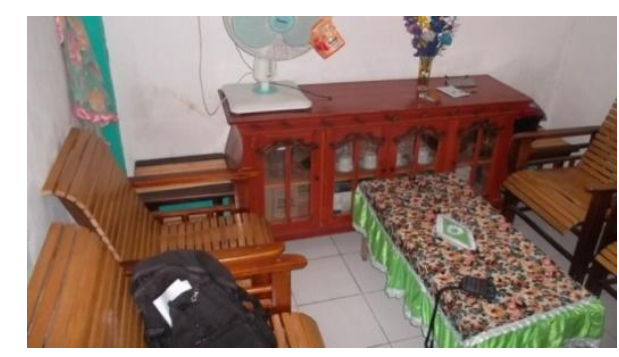

Gambar 4: Pemanfaatan ruang tamu untuk menerima tamu

(Sumber : Penulis, 2017)

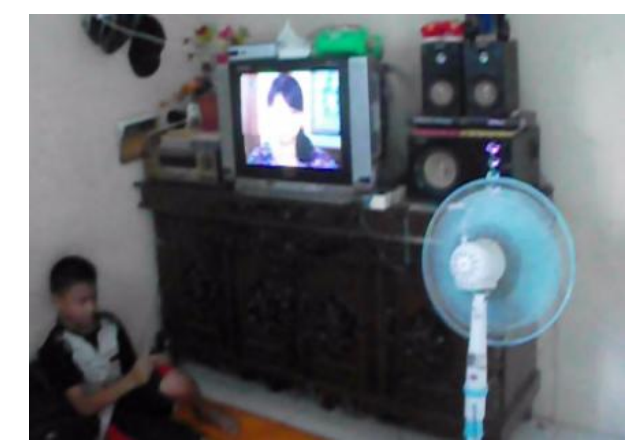

Gambar 5 : Pemanfaatan ruang tamu sebagai ruang keluarga

(Sumber : Penulis, 2017)

\section{Pemanfaatan ruang kamar}

Ruang kamar digunakan sebagai sebagai ruang tidur, ruang untuk menonton tv atau ruang berkumpul keluarga. Pemanfaatan ruang kamar terlihat dari hasil observasi yang dilakukan. Selain sebagai ruang untuk aktivitas tidur, ruang kamar ini juga sekaligus difungsikan sebagai ruang menonton televisi (Gambar 6). Hal ini biasanya dilakukan oleh penghuni yang memanfaatkan ruang tamu tidak sebagai ruang keluarga, misal digunakan sebagai ruang terima tamu.

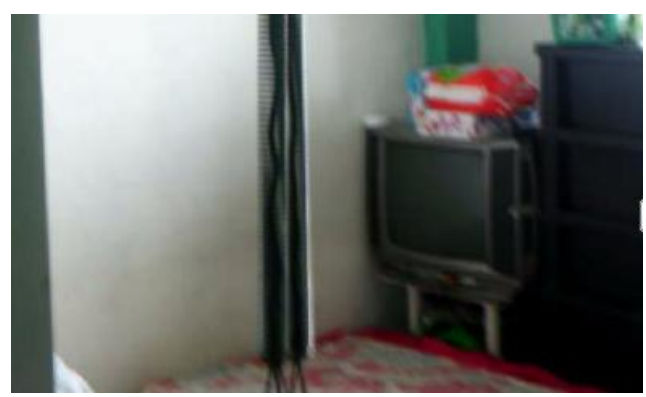

Gambar 6: Pemanfaatan ruang kamar

(Sumber : Penulis, 2017)

\section{Pemanfaatan ruang dapur}

Ruang dapur digunakan sebagai ruang untuk memasak dan untuk 
menempatkan barang - barang. Pemanfaatan ruang dapur sebagai ruang untuk memasak didukung dengan adanya meja dapur permanen yang memungkinkan penghuni dapat langsung memanfaatkannya. Hal menarik dari perubahan yang dilakukan oleh penghuni adalah memperlebar atau memperbesar meja dapur (Gambar 7). Perubahan tersebut banyak dilakukan penghuni karena luasan meja permanen yang disediakan tidak sesuai dengan kebutuhan penghuni, misalnya untuk menempatkan kompor gas atau rak piring. Ruang dapur dimanfaatkan untuk menyimpan barangbarang terutama untuk peralatan memasak dan kebutuhan dapur lainnya, seperti kulkas dan rak piring. Ruang yang paling sering digunakan adalah ruang dibawah meja permanen, baik dengan membuat lemari tambahan maupun dengan meletakkan barang tanpa lemari. Penghuni bahkan memanfaatkan ruang diatas meja dapur sebagai ruang untuk menempatkan barang-barang. Penghuni menambahkan rak tidak permanen yang menggantung di dinding atas meja dapur (Gambar 8)

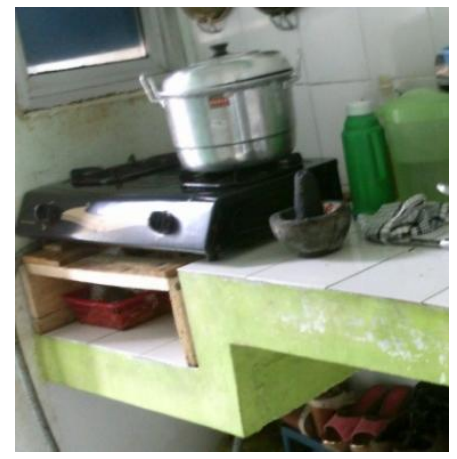

Gambar 7: Pemanfaatan dan penyesuaian ruang dapur dengan mengubah meja dapur (Sumber : Penulis, 2017)

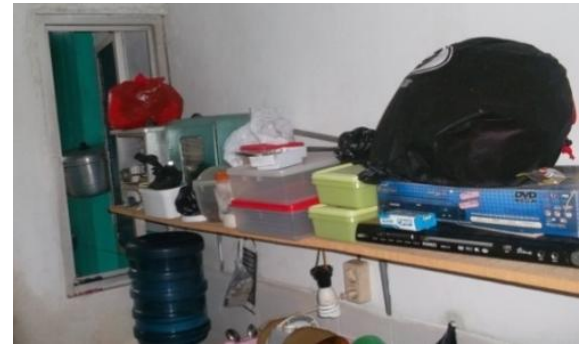

Gambar 8: Pemanfaatan ruang di atas dan atau dibawah meja dapur

(Sumber : Penulis, 2017)
Pemanfaatan ruang balkon

Ruang balkon sebagai ruang untuk menjemur pakaian, sebagai ruang dapur dan untuk menempatkan barang-barang. Penghuni memanfaatkan desain balkon berupa besi - besi pengaman untuk menggantung pakaian yang dijemur. Ruang balkon yang terbuka dengan sinar matahari langsung dibandingkan dengan ruang - ruang lain menjadi kelebihan balkon untuk kegiatan menjemur pakaian. Pada beberapa hunian, ruang balkon dialih fungsikan sebagai ruang dapur (Gambar 9). Hal ini dapat dilihat dari peralatan memasak dan peralatan makan yang diletakkan di ruang balkon. Penghuni mengubah fungsi balkon sebagai dapur dengan menutup bukaan yang terdapat dibalkon. Bukaan ditutup menggunakan plastik atau kain, agar air atau panas matahari tidak masuk pada ruang tersebut. Hunian yang mengubah fungsi balkon menjadi dapur, umumnya menggunakan ruang dapur yang ada hanya sebagai tempat untuk meletakkan barang - barang dan tempat makan. Kegiatan menjemur pakaian, dilakukan penghuni dengan memanfaatkan jendela kamar atau teritisan atau selasar. Ruang balkon juga banyak yang dimanfaatkan oleh penghuni sebagai ruang untuk menempatkan barang - barang baik itu peralatan yang berhubungan dengan kegiatan di dapur seperti rak piring dan lain - lain, juga untuk barang - barang lain yang tidak digunakan setiap saat. Penghuni menganggap ruang balkon merupakan ruang yang memiliki potensi untuk dimanfaatkan sebagai ruang dibandingkan sekedar untuk lubang pencahayaan maupun penghawaan masuk ke hunian. Walaupun demikian, penghuni harus mengorbankan pencahayaan atau penghawaan yang masuk ke dalam hunian dengan menutup bagian balkon, sebagian maupun seluruhnya agar terhindar dari air hujan atau panas matahari. Pada beberapa hunian ada yang memfungsikan ruang balkon ini dengan fungsi ganda misalnya selain sebagai dapur, juga sebagai ruang untuk menempatkan barang - barang, atau selain sebagai ruang untuk barang - 
barang juga sekaligus sebagai ruang untuk menjemur.

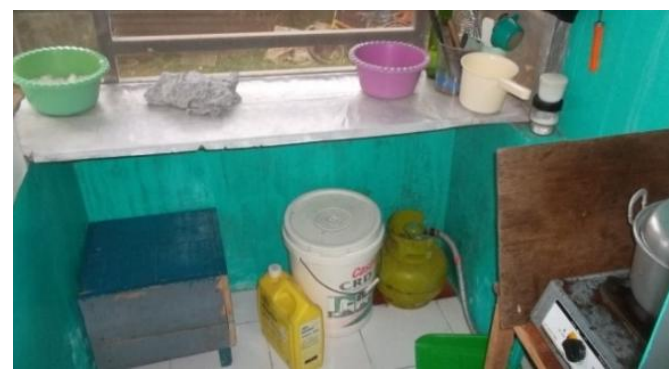

Gambar 9: Mengubah fungsi balkon menjadi dapur

(Sumber : Penulis, 2017)

Pemanfaatan ruang teritisan

Ruang lain yang juga tidak disiasiakan oleh penghuni untuk dimanfaatkan adalah ruang teritisan unit di bawahnya, karena bagian tersebut memiliki level yang sama dengan hunian. Ruang tersebut paling banyak digunakan sebagai ruang untuk menjemur pakaian dan untuk menempatkan barang - barang tidak terpakai atau barang - barang yang hanya dipakai pada waktu - waktu tertentu saja (Gambar 10). Pemanfaatan ruang teritisan ini mirip seperti fungsi ruang gudang. Ada juga yang memanfaatkan teritisan tersebut sebagai ruang untuk menempatkan barang - barang untuk kegiatan hobi seperti penempatan pot - pot tanaman.

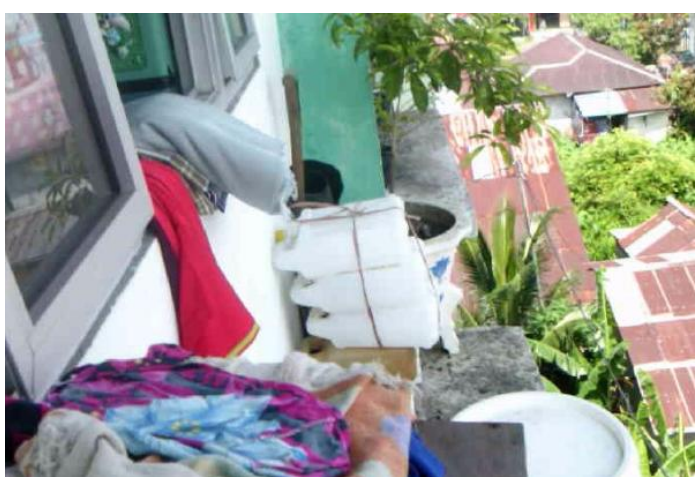

Gambar 10: Memanfaatkan teritisan untuk menjemur pakaian dan menyimpan barang

(Sumber : Penulis, 2017)

\section{Pola pemanfaatan unit hunian}

Berdasarkan hasil paparan yang telah dijelaskan pada bagian pemanfaatan ruang-ruang hunian rusunawa Kota Pontianak, ada beberapa bentuk penyesuaian yang dilakukan pada ruangruang unit hunian tersebut. Pola tersebut sangat terkait antara pemanfaatan suatu ruang dengan ruang lainnya.

Terdapat beberapa bentuk cara penghuni dalam memanfaatkan 1 unit hunian dalam mewadahi seluruh aktivitas yang dilakukan oleh penghuni. Bentuk pertama yang muncul adalah pemanfaatan ruang tamu sebagai ruang keluarga atau berkumpul atau makan dan menonton TV. Untuk menerima tamu, penghuni melakukan perluasan ruang ke bagian selasar. Kegiatan istirahat dan tidur menggunakan ruang tidur, sedangkan untuk memasak dan aktivitas di ruang dapur terkadang diperluas ke ruang tamu. Balkon dan teritisan difungsikan untuk menjemur pakaian atau menempatkan barang - barang (dapat dilihat pada Gambar 11).
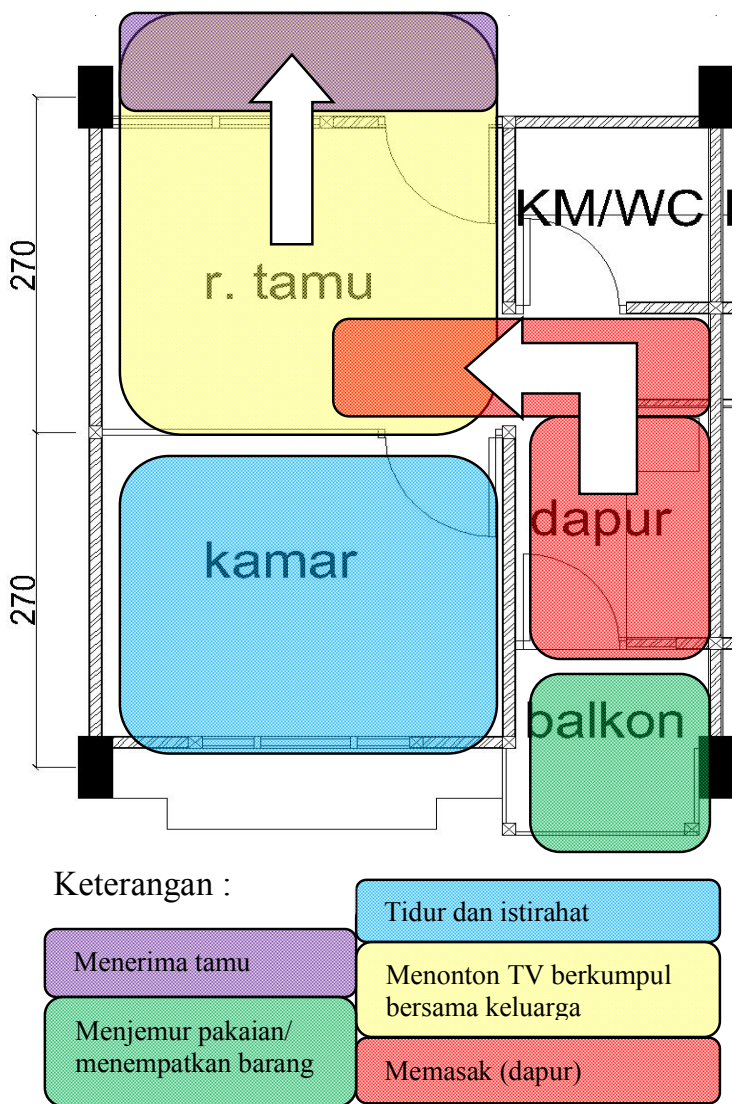

Gambar 11: Bentuk penyesuaian dalam pemanfaatan ruang hunian pola 1

(Sumber : Penulis, 2017)

Bentuk kedua yang muncul adalah pemanfaatan ruang tamu sebagai ruang keluarga atau berkumpul atau makan dan menonton TV. Karena ruang tamu telah digunakan sebagai ruang keluarga atau 
ruang makan, terjadi perluasan ruang ke bagian selasar yang dilakukan oleh penghuni untuk menerima tamu. Kegiatan istirahat dan tidur menggunakan ruang kamar. Perbedaanya adalah untuk kegiatan memasak dan aktivitas di ruang dapur diperluas ke ruang balkon baik dengan merubah fungsi balkon menjadi ruang dapur dan memfungsikan balkon untuk meletakkan peralatan dapur atau barang-barang lainnya. Balkon yang telah berubah fungsi menjadi dapur menyebabkan kegiatan menjemur dilakukan oleh penghuni di bagian teritisan atau ruang selasar (dapat di lihat pada Gambar 12).
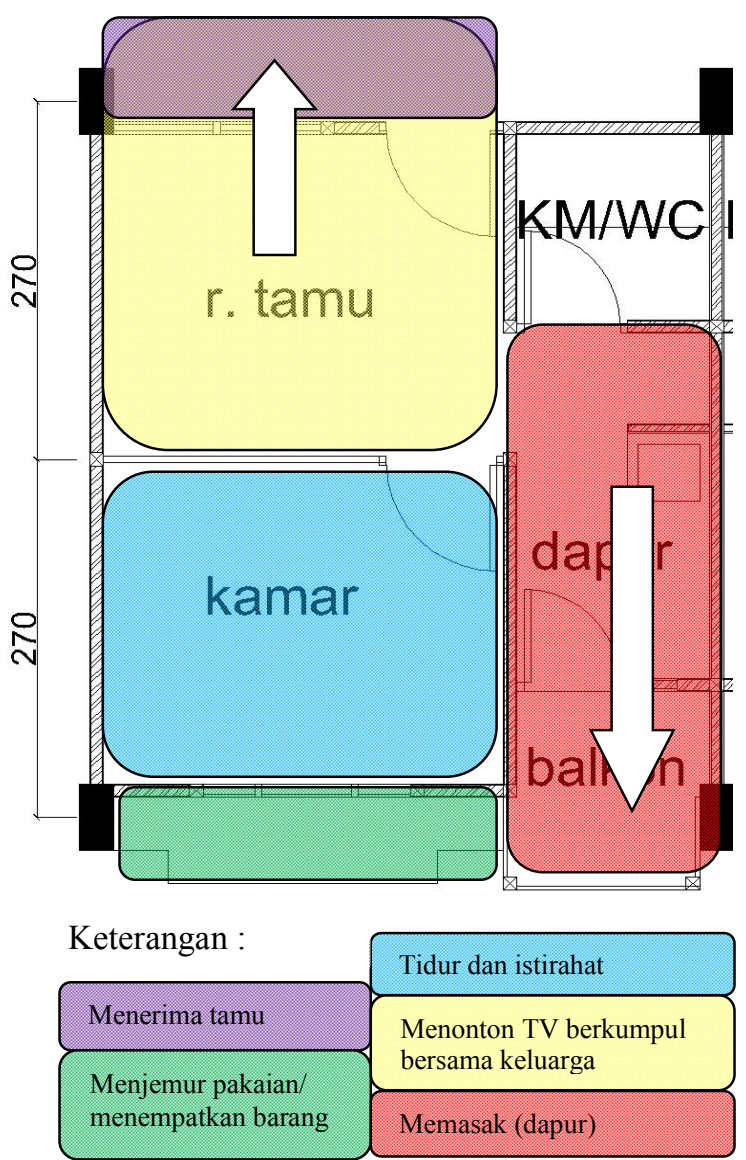

Gambar 12: Bentuk penyesuaian dalam pemanfaatan ruang hunian pola 2

(Sumber : Penulis, 2017)

Bentuk penyesuaian ketiga yang muncul adalah pemanfaatan ruang tamu sebagai ruang keluarga atau berkumpul atau makan dan menonton TV sekaligus sebagai ruang untuk menerima tamu. Perluasan kegiatan berkumpul atau menonton TV dilakukan ke bagian ruang kamar atau sebaliknya. Kegiatan memasak dan aktivitas di ruang dapur diperluas ke ruang balkon baik dengan merubah fungsi balkon menjadi ruang dapur dan atau memfungsikan balkon untuk meletakkan peralatan dapur atau barang - barang lainnya. Kegiatan menjemur dan menempatkan barang barang dilakukan di bagian teritisan atau ruang selasar, misalnya menempatkan rak sepatu dan lain-lain (Gambar 13).
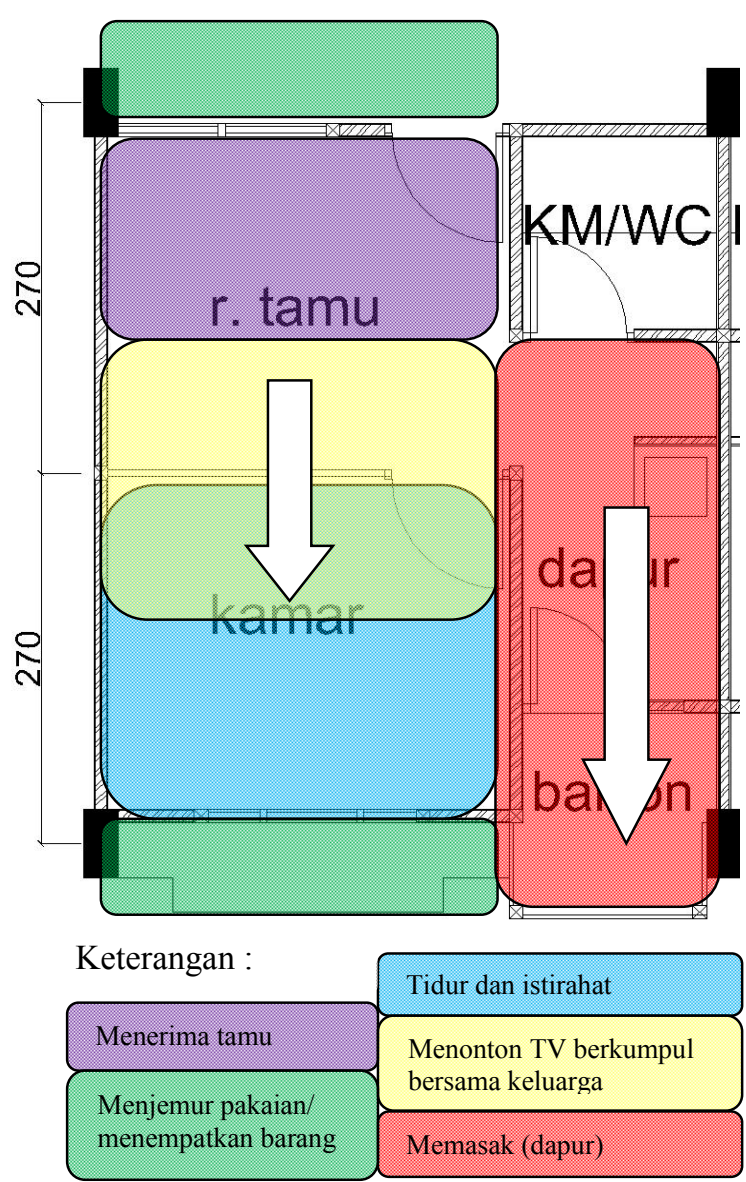

\section{Gambar 13: Bentuk penyesuaian dalam pemanfaatan ruang hunian pola 3}

(Sumber : Penulis, 2017)

Bentuk yang keempat yang muncul adalah pemanfaatan ruang tamu sebagai ruang keluarga atau berkumpul atau makan dan menonton TV sekaligus sebagai ruang untuk menerima tamu. Perluasan kegiatan memasak dan aktivitas di ruang dapur juga dilakukan ke ruang tamu, sedangkan untuk menjemur pakaian atau menempatkan barang- 
barang penghuni memanfaatkan balkon dan teritisan (Gambar 14).

Berdasarkan hasil analisis secara kualitatif, pola pemanfaatan ruang tersebut tidak menunjukkan korelasi yang kuat dengan salah satu faktor karakteristik penghuni atau hunian yang ada. Pola pemanfaatan tersebut tersebar merata pada bagian bangunan baik bangunan blok A maupun bangunan blok $B$. Karakteristik penghuni yang menunjukkan hubungan terletak pada karakteristik jumlah penghuni.
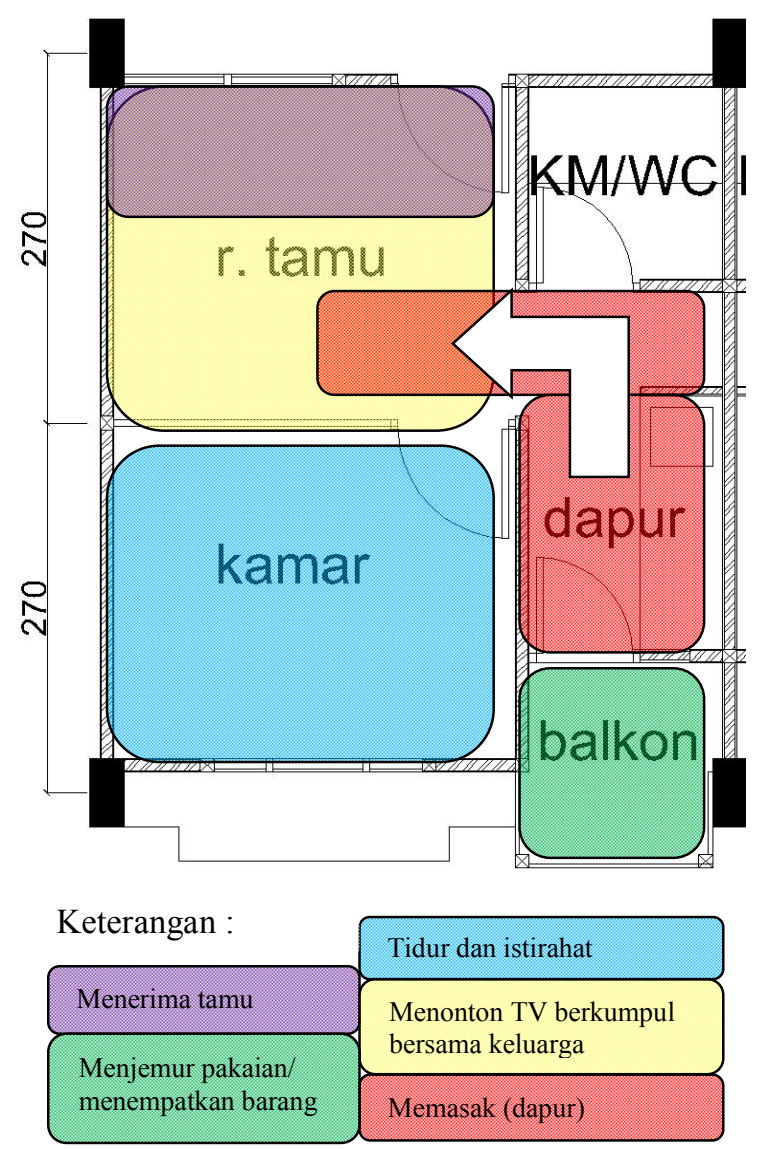

Gambar 14: Bentuk penyesuaian dalam pemanfaatan ruang hunian pola 4

(Sumber : Penulis, 2017)

Penghuni yang memiliki jumlah lebih dari atau sama dengan 3 orang dalam satu unit hunian menunjukkan kecenderungan memperluas ruang untuk kegiatan (aktivitas) baik dengan memanfaatkan ruang yang menjadi hak penghuni seperti ruang balkon dan teritisan, maupun memperluas ruang untuk aktivitas kebagian ruang bersama seperti selasar.

\section{PENUTUP}

\section{Kesimpulan}

Hasil penelitian ini dapat disimpulkan:

1. Penyesuaian dalam memanfaatkan ruang dilakukan penghuni terutama untuk memenuhi kegiatan utama yaitu, berkumpul keluarga atau menonton bersama, menerima tamu, tidur makan, dan kebutuhan MCK

2. Penghuni berusaha memanfaatkan ruang yang ada dan melakukan perluasan ruang untuk aktifitas dengan mengubah fungsi ruang terutama fungsi balkon dan selasar.

3. Terdapat 4 bentuk umum dalam menafaatkan ruang - ruang yang ada pada rusunawa kota Pontianak.

\section{Saran}

Penelitian berikutnya dapat dilakukan untuk melihat hubungan keterkaitan antara penghuni atau ruang dengan karakteristik penyesuaian dalam memanfaatkan ruang menggunakan metode kuantitiaf sebagai keberlanjutan dari temuan pada penelitian ini. Peneltian serupa juga dapat dilakukan pada rusunawa-rusunawa lain untuk dilihat perbandingan dengan penelitian yang telah dilakukan.

\section{DAFTAR PUSTAKA}

Agrawal, Sadeep Kumar . (2006): Housing Adaptations : "A Study of Asian Indian Imigran Home in Toronto". Canadian Ethnic Studies, 38 (1), Proquest, 117 ;

Darmiwati, R. (2000): "Studi Ruang Bersama dalam Rumah Susun bagi Penghuni Berpenghasilan Rendah". Dimensi Teknik Arsitektur, 28 (2), 114-122;

Ibem, E.O., Amole, D. (2012): "Residential Satisfaction in Public Core Housing in Abeokuta, Ogun State, Nigeria". Springer Science Business Media B.V., 563-581;

Laurens, Joyce Marcella. (2004) : "Arsitektur dan Perilaku Manusia". PT Gramedia Widia Sarana Indonesia, Jakarta;

Purwanto, Edi, Wijayanti. (2012): "Pola Ruang Komunal di Rumah Susun Bandarharjo Semarang". Dimensi Teknik Arsitektur, 39 (1), p.29-30;

Sarwono,Sarlito Wirawan. (1992): "Psikologi Lingkungan". Grasindo, Jakarta ;

Septyadinda, L. Sari, I.K., Hariyono, P. (2013): "Peran Balkon Pada Rumah Susun dan 
Apartemen". Jurnal Tesa Arsitektur, 11(1), 64-76;

Tester, Griff., et al. (2011): "Sense of Place among Atlanta Public Housing Residents". Journal of Urban Health, 88 (3), p.436453;

Zain, Z., Lestari., Khaliesh, H., \& Sari, I.K. (2015): "Karakteristik Unit Hunian dan Penghuni pada Rumah Susun Sederhana Sewa (Rususnawa) di Kelurahan Sungai Beliung Kota Pontianak". Jurnal Nalars, 14(2), 83-95; 